\title{
Re-visiting the notion of Deep Incarnation in light of 1 Corinthians 15:28 and emergence theory
}

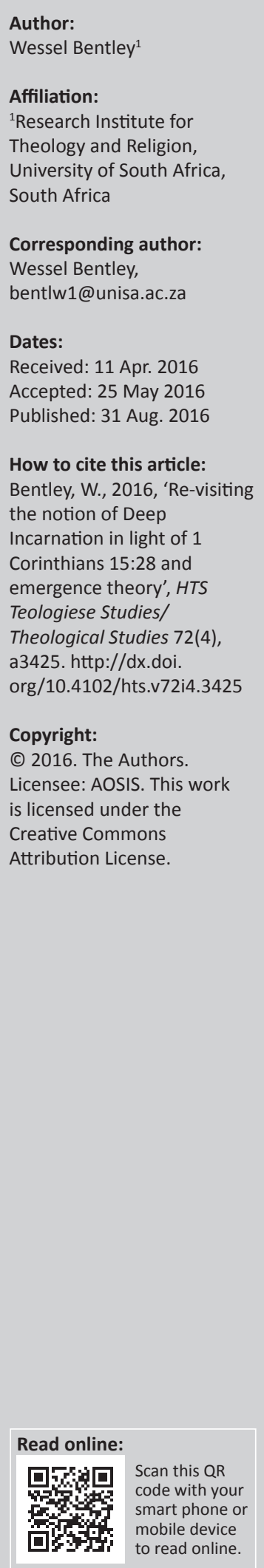

Niels Hendrik Gregersen's 'Deep Incarnation' is opening up possibilities for engagement between science and theology. Recent discoveries, like that of Homo naledi, raise questions about how inclusive a Christian doctrine of Incarnation is. Is Jesus only God incarnate for Homo sapien sapiens, or is the incarnation inclusive of preceding hominid species as well? Does the incarnation stretch beyond the hominid line? This chapter engages Gregersen's understanding of Deep Incarnation in light of 1 Corinthians 15:28 and emergence theory. It proposes that there is a direct correlation between worldview and how we believe in the inclusive nature of divine incarnation.

\section{Introduction}

On 10 September 2015, Prof. Lee Berger announced the discovery of a previously unknown species of extinct hominid, which he and his team named Homo naledi. Although this discovery has been met with some scepticism, one of the most intriguing finds has been that $H$. naledi seemed to have buried their dead. Several sets of bones were found together in a chamber, not easily reachable from the outside. ${ }^{1}$ From an anthropological perspective, the act of placing the dead in a designated place, and not leaving the bodies of community members in the vicinity of their demise, suggests a relational understanding which distinguishes $H$. naledi from other species of 'animal' and hominids at that time. Of course it is too early to suggest that the burial of their dead can be associated with the practice of religious rituals. It nevertheless beacons the question: was H. naledi a religiously-aware creature? And if so, does it matter?

Now, here I am in 21st century South Africa, fascinated by this find. As a theologian, I am confronted by theological questions concerning our place as humans in this vast expanse of time and space. Theologically speaking, $H$. naledi's recognition of the difference between life and death, and the deliberate acts of keeping the dead in one place, suggests religious undertones. Or is such a reading of events merely the product of my own modern association of religion with notions of transcendence? Whatever the answer may be, there is a kinship, a shared identification with $H$. naledi which we as modern humans cannot ignore. ${ }^{2} H$. naledi is an ancestor of modern humanity. $H$. naledi is family. Perhaps if $H$. naledi could see us today, it would not be inappropriate for them to comment: 'This is bone of my bones and flesh of my flesh'. ${ }^{3}$

To identify a theological-biological anthropology ${ }^{4}$ which links humanity to $H$. naledi is an interesting task. Of greater theological significance would be how we speak of a doctrine of God, especially the relevance of Christology in light of this find. Let me risk asking the following questions: If there is a biological-relational link between modern humanity and $H$. naledi, then do we share the same saviour? Or was Jesus meant only for H. s. sapiens? These questions form a backdrop to this article's discussion on Deep Incarnation.

\section{On Incarnation and Deep Incarnation}

Largely attributed to Niels Hendrik Gregersen, the term 'Deep Incarnation' refers to a Christology which suggests the following:

1.The evidence suggests that this was not a so-called 'death-trap' (where several individuals may have become trapped in a cavern and died there), but that this was a designated place to lay the dead to rest.

2.Although published before the announcement of Homo Naledi, the relationship between modern humankind and earlier Homo genus species is well described in Harari (2015).

3.This is a play on the words by Adam in Genesis 2:23 when he first encountered the woman, whom he later (Genesis 3:20) named Eve. 4.I use the term 'biological anthropology', as classic anthropology is more inclined to study human-hood in light of culture, worldview and the like. Biological anthropology focusses on the biological lineage of human-hood. I thank Prof. Cornel W. du Toit for this insight.

Note: Original Research: Volume 17 in the South African Science and Religion Forum Series, edited by Prof. Dr Cornel du Toit (UNISA) and Prof. Dr Danie Veldsman, entitled 'Creation, Consciousness and Christology: Evolutionary Perspectives', Proceedings of the 20th conference of the South African Science and Religion Forum (SASRF) of the Research Institute for Theology and Religion held at the University of South Africa, Pretoria, 16-18 September 2015. 
Without a strong continuity between the historical figure of Jesus and the cosmos at large, we end up in a culturally confined Christology. But without referring to the unique human identity of Jesus Christ, we would speak of a Logos principle thinly spread over the universe rather than of Jesus Christ as the living divine bond in and between everything that exists. Incarnation is 'deep' both in contradistinction to a purely anthropocentric Christology and as opposed to more shallow proposals of a universalist Christology. (Gregersen 2010:173)

Deep Incarnation offers a fresh theological perspective; Divine Incarnation in the person of Jesus Christ that is not only to be interpreted as God manifest in the body of a human being, but that the Incarnation points to God's presence in, and association with '.. the whole malleable matrix of materiality' (Gregersen 2010:176). It nevertheless should not be confused with pantheism.

Whether one speaks of an anthropocentric Incarnation, or Gregersen's 'Deep Incarnation', there are a few confessions that initially need to be made. Firstly, we must admit that any talk of Incarnation or explanation thereof on our part is done sub specie temporis, perhaps more specifically sub specie anthropos, making our description rather speculative and subjective. ${ }^{5}$ Not only do we speak about Incarnation from our own place in time and space, but we do so from our own level of complexity, understanding and worldview. Our description of the Incarnation is contextually locked within the limitations of human existence, experience and knowledge, allowing us to interpret the Incarnation, using solely our own frame of reference.

It is important to make this admission, as it reminds us that the truths to which we hold are largely coloured by our vantage point. Regarding worldview, for instance, it is easy to prove the existence of the correlation between cosmological understanding and theological appropriation. ${ }^{6}$ For example, it is well known that the Biblical three-tiered universe dictated the doctrinal understandings of Christian belief for most of the last two millennia. ${ }^{7}$ Stemming from the understanding that the earth exists as a flat surface with heaven above and hell below, it was plausible for God to be spatially removed from creation. It was not difficult to imagine God as one who looks down from above, acting as a supreme creator and eternal judge. The doctrine of the Incarnation did not remain unscathed; God 'came down' from above to live in the domain and context in which we were created, thus facilitating the time, space and meeting point between heaven 'above' and humanity 'below'. Further to this, the reference to Jesus' 'descent into Hell', 8 as professed in amongst others the Apostles Creed, completes the picture of a three-tiered universe and of God, who through the Incarnation, regained

5.The speculative nature of this perspective is further described by Stuart A. Kauffman (2015:289-308).

6.I use the word 'appropriation' as I contend that theological discourse is primarily a human undertaking to understand the transcendental relationship between God and the cosmos.

7.For a diagram depicting the Biblical three-tier universe, see Denis O. Lamoureux (2011:82).

8.See for example Acts 2:24, Ephesians 4:9 and 1 Peter 3:19 as early Christian understanding of Christ's redemptive work by descending to 'Hell'. control over all levels of the cosmos. Needless to say, with our modern understanding of the universe, we have to critically rethink our theology. Stubbornly refusing to surrender a threetiered universe validates the arguments of the so-called New Atheists, who postulate that religion has lost touch with reality, and is nothing less than an archaic and dated premodern worldview which confines people in their ignorance (Dawkins 2006:282-288). How do we then bridge the gap between traditional Christian orthodoxy and modern scientific knowledge? To answer this question we start with a review of how we read the Bible in light of unfolding scientific knowledge.

Now, a second admission: to superimpose modern cosmology onto Biblical texts is bad science, whereas superimposing Biblical texts onto modern cosmology is poor hermeneutics. ${ }^{9}$ Pointing to the first part of the admission for instance, the argument that the 7-day creation narrative of Genesis 1 refers to seven different eras rather than seven literal days, does not resolve any dispute between science and theology. Regarding the latter, to quote Hebrews 13:8 to prove quantum theory and relativity is an equally futile exercise! The best we can do is to interpret Scripture honestly and rigorously in its own context while keeping an open mind to new knowledge gained about our universe. To me, this is the task of the modern theologian: to play a critical role of facilitating a dialogue whereby the gift of religion (including the Bible) can continue making a relevant and positive difference in this world, while resisting the trap of succumbing to apologetics. Theologians, now more than ever need to keep abreast with scientific knowledge and not excuse their lack of engagement by taking an apathetic stance, perhaps resorting to Gould's non-overlapping magisteria (NOMA) (Gould 2002) as their safe haven (cf. Meddings 2013:19-20) - which, by the way, is a misrepresentation of Gould's argument.

How then can we speak of Incarnation, while holding Scripture (read Christian tradition) and scientific knowledge side-by-side? Is Gregersen's 'Deep Incarnation' a successful attempt at rethinking theology which is both true to its ancient roots while at the same time positively engaging with recent scientific knowledge?

It is my argument that when we look at a Pauline Christology such as summarised in 1 Corinthians 15:28 and hold it as a template against Gregersen's 'Deep Incarnation' (as well as what we know about complexity and emergence theory), then possibilities arise whereby Christology, but more so, the doctrine of Incarnation can become itself a new hermeneutical lens through which theology engages with science. It can do so without compromising or reinventing the contextual intention of Scripture.

\section{Paul and Gregersen: Common themes}

One of the reasons I chose 1 Corinthians $15: 28$, is that it is commonly used as a focal passage for Christian eschatology.

9.Giberson (2015:24) phrases it this way: '... bringing inappropriate modern questions to an ancient text'. 
Richard Bauckham, for instance, notes that Jürgen Moltmann uses this text more than any other in the construction of his eschatological theology (cf. Bauckham 1999:xv). I agree with Moltmann's understanding that Christian eschatology has a two-directional relationship with the other major Christian doctrines. For example, what we believe about eschatology shapes the way we interpret Christology and vice-versa (cf. Moltmann 1990:213-233; 1996:29-46). 1 Corinthians 15:28 reads as follows:

'When all things are subjected to him, then the Son himself will also be subjected to the one who put all things in subjection under him, so that God will be all in all'. (NIV) ${ }^{10}$

There are three notable points in this passage:

- the distinction between God (in the text referring specifically to the Son) and all other 'things' - 'When all things are subjected to him ...'

- the distinction between the First Person of the Trinity and the Son - '... then the Son himself will also be subjected to the one who put all things in subjection under him ...'

- the aim of it all (the eschatological point), is the reconciliation between God and 'it all' - '... so that God will be all in all'.

Reading Paul's letter, we have to keep in mind that Paul adhered to the dualistic, three-tier cosmology of his day, strongly differentiating between pneuma and sarx. ${ }^{11}$ Paul elevated the space of God and spirit above the material existence of creation, ${ }^{12}$ suggesting that the Incarnation of Christ required a transition from the eternal to the temporal, from the spiritual to the physical, from the Divine reality to a material reality. From a philosophical-existentialist perspective, it seems almost impossible for this transition to take place without the substance of the Incarnation needing to be transformed, 'losing' some of its primal characteristics in order to adapt to the new context. The Pauline Christology and Soteriology of 1 Corinthians 15, alludes to the Incarnation as the meeting point between God and humanity. God, in the person of Jesus becomes flesh, lives, dies and through the resurrection starts the eschatological move of reconciling all things to God and God to all things.

To get back to our philosophical-existential problem, the obvious question is: how does God do this (the transition from the divine reality to the material)? As a response, Christian traditional has found comfort in the doctrine of Kenōsis ${ }^{13}$; a self-emptying, where Jesus, through the Incarnation surrenders aspects of God's 'otherness' in order to manifest in the flesh. ${ }^{14}$ From Paul's cosmological frame of

10.The Holy Bible, New International Version, Textbook Edition (Grand Rapids: Zondervan, 1984).

11.See Engberg-Pedersen (2009:179-197) for a description of Paul's cosmology, deduced from his use of these terms.

12.I need to add a disclaimer: By using the term 'creation', I acknowledge that it is used in both theological and scientific discourse, implying a measure of creationism. I do not intent to use this term according to this definition, but to refer to the cosmos, or the universe as we know and experience it.

13.The clearest reference to a doctrine of Kenōsis is found in Philippians 2:7, where the verb 'keno-o' is used to refer to the deliberate stepping down from the eternal into the temporal (cf. Karo and Friedenthal (2008:824).

14.For a concise summary of the doctrine of kenosis, see Walker (2015). reference, there is no problem in adopting Kenōsis as an explanation for the Incarnation. The only way for God to become real in the earth 'below' is to set aside that which confines God to the 'above'. From our cosmological understanding, Paul already loses us when he implies a three-tier cosmology and how the Incarnation takes place in it.

Considering Deep Incarnation, Gregersen and other proponents of it use a similar schema to that mentioned in 1 Corinthians 15:28. Obviously, our modern cosmology differs significantly from that of Paul's, but Deep Incarnation is nevertheless presented with the following doctrinal premise:

- a distinction between God and creation

- a difference in the presence (and absence) of the Persons of the Trinity in creation

- an aim of a reconciled state between God and creation.

The difference between Paul's Incarnation and Deep Incarnation is not only on the basis of cosmology; where Pauline Incarnation is anthropocentric, Deep Incarnation argues that God did not only become human in the person of Jesus, but through the Incarnation, God assumes a human body in the natural world with all its evolutionary progress and processes. In this instance, Joshua Moritz draws our attention to a different understanding of Incarnation where Jesus is described as the 'second Adam' (Moritz 2013:436-443). The first Adam, for all means and purposes is an anthropocentric being, personifying the individual selfabsorption of humanity which becomes the foundation for what would later become 'the Fall'. 'The Fall' resembles humanity's break from relationship, not only with God, but its self-separation from creation and community.

Rather than forming part of creation, humanity sees itself as the special bit of God's creative plan, empowered to rule and to subject. 'The Second Adam', on the other hand, emphasises the intrinsic nature of relationships in creation, encapsulating through the Incarnation the entirety of the relational complexity of the cosmos in the presence of God. By doing this, the Incarnation does not merely elevate one species, namely H. s. sapiens, to the status of being created in Imago Dei. Before we go further along this line of argument; let us look at the common underlying themes in Pauline- and Deep Incarnation.

\section{The distinction between God and creation}

The first point is that of the distinction between God and creation. When we speak of a distinction, we imply a causal differentiation between two or more categories. Traditional Christian theology, which includes the insights offered by Paul, identifies 'sin' as the origin of the schism between God and creation (Edwards 2015:159). Moltmann (2015:95) rightly asserts that the doctrine of Incarnation is heavily reliant upon, and even undergirded by soteriology. God became flesh because we needed to be saved, redeemed, reconciled, 
and so forth. We need to be saved, redeemed and reconciled, because sin, the damage in humanity's relationship with God, creation and within itself, needs to be remedied. As classic soteriology advocates, humanity cannot achieve this reconciled state on its own. Only God can do so and chooses to 'reconcile from below' by becoming flesh and restoring humanity's place with God. This reconciled state would further imply a growth towards restored human relationships and humanity's relationship with the rest of creation. Incarnation becomes the bridge between God and creation, the means by which the process of salvation becomes tangible. Pauline Christology goes one step further: The nature of the distinction between God and creation is not a horizontal separation of two equal entities. Salvation is neither described in terms of achieving perfect equality between God and creation. According to 1 Corinthians 15:28, even in the act of reconciliation there is still a hierarchical distinction between God and creation: 'When all things are subjected to him ...' The distinction between God and 'all things' manifests on several levels, amongst others, the distinction between creator and creation, eternal and temporal, redeemer and the redeemed. God remains God and creation remains, well 'not-God'. To be reconciled does not imply that creation becomes God, for creation can never ascend to God's 'level'.

The language of such division is fixed in dichotomous terms; God is placed outside the context of creation and has to cross self-limiting boundaries ${ }^{15}$ in order to achieve restoration. There are a few problems that arise with this view. Firstly, a frivolous remark: the dilemma with a term like 'Incarnation' is in the prefix ' $\mathrm{In}^{\prime}$. The ' $\mathrm{In}^{\prime}$ ' in Incarnation presupposes that that there must be a context of an 'Out'. The assumption is that although the 'all things' are located in creation, God is situated in the out. A dichotomous locality of God and creation automatically disqualifies any Christian notion of true pantheism or panentheism, yet it requires a special event like the Incarnation to facilitate a common meeting point between God and creation.

Secondly, it creates a problem of theodicy. How is it possible for God who is located fundamentally outside the realm of creation to show any kind of empathetic relationship with creation? When the 'all things' in creation experience suffering, and locate God in the perfect and harmonious 'out' where suffering does not exist, it is only natural for 'the all' to equate creation's suffering with some form of punishment by God or God's complete disregard for the plight of the created. It may be argued that Jesus addressed the question of theodicy in John 9:1-12, echoing the teaching of the Book of Job where suffering is seen neither as punishment for sin nor the product of generational transgressions. The counterargument is that both these portions of Scripture place God as a Divine observer, and in both instances allows suffering in order for a larger point to be proven.

Thirdly, classic Incarnation, Christology and soteriology do not make space for human evolutionary history. Rightly so,

15.This requires a doctrine of Kenōsis. as evolution theory is a relatively recent addition to human knowledge. When we speak of salvation, Christian theology naturally refers broadly to the salvation of humanity, opening the bracket at the first human (a literal or mythological Adam) and closes the bracket with humanity at the eschaton. The whole of salvation history is defined by the working of God, who is above all and over all, within the history of this bracketed section of humanity. This description is consistent and congruent with a three-tier model of the universe and of humanity, created in the image of God and thus devoid of any evolutionary processes. But is there another way to interpret the distinction between God and creation?

Considering our recent understanding of the universe, Deep Incarnation in response to both evolutionary biology and traditional Christian theology, needs to differentiate between two options. The first option is to follow the traditional doctrine of Incarnation, where it draws a sharp distinction between the ontological being of God and the existence of the cosmos. The 'otherness' of God is emphasised and sets the scene for Jesus as God breaking into the created sphere, specifically the world of human beings. Deep Incarnation suggests that the 'totally other' God takes on the totality of humanhood, which includes both the exact evolutionary point where humanity stood at the time of the Incarnation as well as encapsulating all of its preceding evolutionary history. This option would still require Deep Incarnation to solve the mystery of the hypostatic union, which I believe will lead to an unhelpful loop where Deep Incarnation will seek to justify itself and/or classic Christology by adapting and superimposing Scripture onto modern scientific theory. As stated earlier, such an approach is neither responsible nor feasible.

The second alternative suggests that God, the highest form of complexity, through the Incarnation, takes the form of a lower level of complexity. This idea is enticing, for it would place God in a realm where God operates on a level of unique 'laws' which are specific to God's dimension of reality perhaps where God is God's own level of reality. These 'laws' in God's level of complexity would include that God is not bound by space, time or any of the known dimensions in our reality. It also links God intrinsically with all lower forms of complexity, including our level of awareness. Incarnation is then the fullness of the complexity of God revealed at the level of human reality, which includes the laws at which human beings operate. Regarding revelation, it would then imply that God experiences and is made known in a product of evolution (Schaab 2013:634).

It is interesting that Deep Incarnation defines the distinction between God and creation, using information as difference (Gregersen 2013c:394; Rolston 2015:255-288). In complexity theory, information is not regarded as hierarchical, but rather as progressive. Emergence theory shows that although each level of complexity operates within its own set of laws, the information located at this particular level of complexity becomes the foundation for the emergence of new levels of 
complexity, which then in turn operate within its own natural parameters.

To apply emergence theory to Deep Incarnation, we need to take cognisance of two different forms of complexity. The first can be defined as horizontal complexity. Here, we differentiate broadly between the differences in one spectral band that is found in, for instance, different hominid species. Modern humanity (H. s. sapiens) would object if there were no distinction described between itself and an earlier hominid species such as, for instance, Homo erectus or the example used earlier of $H$. naledi. The question here once again is whether the Incarnate Christ is meant only for $H$. s. sapiens, or whether other species in the hominid spectrum are also included?

The second form is that of vertical complexity. Here, we speak of levels of complexity that differentiate between divergent orders which function on their own appropriate levels. The question which arises here is whether the Incarnation includes all levels of complexity. If this is the case, then it would mean that Jesus is not only Incarnate for humanity, but Jesus is at the same time God Incarnate for the quark and for the multiverse! Complexity in the doctrine of Incarnation leads us to the notion that there must be more to the Incarnation than simply the event of God becoming human in order to redeem humankind alone (Moritz 2013:436).

This understanding of Incarnation in light of emergence theory is not too far off, as Gloria Schaab (2013) suggests, and becomes a game changer in how we speak of for instance, the relationship between soteriology and ecology. Deep Incarnation requires an inseparable union between God and creation, but without falling into the trap of pantheism or panentheism. God, as the manifestation of a higher order of complexity in our world, is naturally distinct from all lower levels of complexity. Schaab (2013:636) emphasises that the Incarnation is a:

'Coincidence of opposites', whereby God becomes flesh, while not mutating or transforming. 'Incarnation is already a potential that is actual in God. The change is in the being of "another," the cosmos'. (Schaab 2013:636)

We must ask: do we then here have to do with an anthropic principle - that evolution was geared toward the emergence of humankind and that the 'being of God is finely-tuned for the emergence of the Word-made-flesh in time'? (Schaab 2013:636). The answer to this is ' $\mathrm{No}^{\prime}$. In short, as humans we can only be aware of God Incarnate in the person of Jesus, as this is where God manifests in a language that we understand. As for other levels of complexity, the Incarnation is and must be real within the realities of such levels. From this perspective, the relationship between God and creation can be summarised as follows: God is while creation is becoming, and creation becomes while God is. In all of these processes, God who is distinct, makes Godself known in creation for the purpose of reconciliation.
The initial step of the Incarnation, taking the distinction between God and creation into account, is for the lower levels of complexity to be aligned with the self-manifestation of God at this level ('When all things are subjected to him ...'). Now, for the next dilemma: The distinction between the First and Second persons of the Trinity.

\section{The distinction between the First and Second persons of the Trinity}

If God is, while creation is becoming, and creation becomes while God is, then how do we make sense of the First and Second persons of the Trinity existing in such different realms of reality? When we look at Paul's understanding, it is notable that Paul's Christology hinges on a strong anthropocentric location of both the cause of and remedy for $\sin$. 1 Corinthians 15:47-48, the passage following our core text, draws our attention to this point. To Paul, the distinction between God and humanity is accredited to the fall of the 'first Adam'. In turn, the salvific work (of Christ) is ascribed to the being and work of the 'second Adam'. The problem is hence not with God or God's realm, but is a dilemma which needs to be addressed within the realm of creation. As God is the only one who can address the schism, the Incarnation becomes necessary and God becomes flesh. Based on the previous point of the distinction between God and creation, particularly the distinction between God and humanity, Incarnation points to God becoming human, God becoming 'created'. Pauline Christology poses the reality of the schism between God and creation as a Divine problem: it is now also a question of distinction within the Godhead where God is God, but at the same time God is also 'creature'. This distinction is evident in Paul's salutations in the epistles, for instance 1 Corinthians 1:3, 2 Corinthians 1:2, Galatians 1:1, Philippians 1:1, 1 Thessalonians 1:1, and so on. ${ }^{16}$

What exacerbates the problem of the distinction between 'God our Father and the Lord Jesus Christ' is that Paul's Christology alludes to the pre-existence of Christ. Romans 8:3-4 serves as an example of this. So, God sends the Son who according to the Gospel of John (as 'The Word') - is with God and is God (Jn 1:1). In the Incarnation, the Word becomes flesh, and is affirmed at His baptism as 'the beloved Son' (Mt 3:17). Paul makes sense of this transition by using the term 'morphe' in Philippians 2:6, suggesting that although God became flesh, the essential divine character of the Incarnate Christ remained unchanged. To do so, nevertheless required 'kenóo' ${ }^{\prime},{ }^{17}$ a self-emptying, the setting aside of His divine state in order to manifest in the likeness of human flesh. From this Incarnate mode, the Son is able to be fully God, and while representing humanity, is the perfect mediator for reconciliation. In summary, the Son becomes flesh, receiving 'all things' in subjection under Him, and then as part of humanity (and along with humanity) is subjected to the '... one who put all things in subjection under him ...'. The distinction between the First and Second Persons of the 16.Paul consistently differentiates between 'God our Father and the Lord Jesus Christ'. 17.See Philippians 2:7. 
Trinity is functional and not as complicated as the debates that surrounded the issues of either the Councils of Nicaea (325 AD) or Chalcedon (451 AD). This explanation of the distinction between the First and Second Person is congruent with Paul's worldview.

Also, again, we need to remind ourselves that we are trying to describe this aspect of the Incarnation sub specie temporis (anthropos). From this vantage point, we try to tell the story of the Incarnation using, amongst other parameters, our concept of time. If we were to place a pin on the timeline of the Incarnation-event, then we will naturally ask questions about the 'before' and the 'after'. Who was Christ before the Incarnation? Who is Christ after the Incarnation? This leads us further to other dimensions, such as space or locality. Where was Christ before the Incarnation? Where is Christ after the Incarnation? Trying our best to make sense of how it is possible for God to be fully present in the Person of Jesus Christ is as daunting as attempting to describe my physical presence at the atomic level of this blob of matter which I know as my body. Yet, I know that I am fully present even at the atomic level and I can do so without compromising who I am at the level of complexity where I experience consciousness. My point is that that which constitutes a problem 'for the atoms', is not necessarily a problem for me, and similarly the Incarnation may not be as big a problem for God as what it may deem to be for us!

The problem for us is not solved by Kenōsis, as Kenōsis assumes a linear framework of time, space and locality. Our question is rather whether it is possible for something (God) to simultaneously and consciously exist at two different levels of complexity? We know that at lower levels of complexity, it is indeed possible for something to exist at two locations at the same time. So, if the Incarnation-distinction merely raised questions about dual locality, then we already have models in quantum theory that can make sense of such a dilemma (Chown 2014).

The unexplained possibility of God being fully God and fully present in the Second Person leads us to what seems to be a 'cop-out' explanation: It literally takes God to be fully present both in God's level of complexity and in ours. This is quite a romantic explanation, but it is nonetheless congruent with what we know about complexity theory; we cannot superimpose our laws of physics (or worldview) onto higher levels of complexity. Furthermore, perhaps we should not get too bogged down in the 'how' of the distinction between the First and Second Persons, but rather ask 'why?' If we focus on the 'how', then we will fall into the same quandary identified by Peterson: the eventual assumption that Incarnation implies that the First and Second Persons of the Trinity exist in seemingly mutually exclusive states, possessing different characteristics (Peterson 2014:246).

Drawing from a high Christology, Gregersen's Deep Incarnation argues that, like Paul's functional distinction, the Incarnation makes it possible for the process of reconciliation to be facilitated. Not only are we to see the Incarnation in existential terms, but the metaphorical value of the divine distinction is already a point of contact between God and creation. Gregersen puts it in the following way: 'The Father symbolises the highness of God, the Son the lowliness of God, and the Holy Spirit the divine capacity to overcome the abyss between high and low' (Gregerson 2001:203). Notably, Gregersen unlike Paul, already here locates the Third Person of the Trinity. Does he perhaps draw from Augustine's explanation of the Spirit being the bond of love between the Father and the Son? Nonetheless, the distinction is invaluable in describing the inseparable, yet distinct connection between God and creation in the unity and distinction of the Father and the Son. This point is further expounded upon in the Lutheran influence ${ }^{18}$ of Deep Incarnation. Referring to the cross, Gregersen (2001) points out that:

... There is no longer any opposition between God's glory and the humiliation of Jesus. God's heavenly glory is stretched so as to encompass the soil of the cruciform creation. (p. 203)

Where Deep Incarnation goes further than Paul's approach, is by suggesting that Jesus is not only distinct from the First Person by becoming human and representing humanity, but that God, in the Incarnation takes on all forms of life, even that preceding humanity in '... the expanse of evolutionary existence' (Schaab 2013:634). This includes all its processes, even the 'brokenness' of creation manifest in disease and decay (Gregersen 2001:193). Seeing that the Incarnation is not just skin deep (Gregersen 2013b:260) in the Person of Jesus as human, the distinction in the Incarnation becomes so much richer; Jesus personifies and concretises the distinction between God and the whole of creation, making reconciliation possible not only between God and humanity, but God and the entire realm of creation (Gregersen 2013a:383).

\section{Reconciliation between God and creation}

Lastly, the aim of the Incarnation, as mentioned earlier, is stooped in soteriology. Perhaps we can add 'an eschatological' soteriology. Note that I say 'eschatological', not 'apocalyptic'. Paul asserts the notion of a goal-orientated Incarnation in the following way: '.. so that God will be all in all' (1 Cor 15:28). Although Moltmann (1996:235) and others appropriate this phrase to mean something that resembles a cosmic eschatology, it is not to say that Paul had a similar idea in mind. How much 'all' is in Paul's 'all'? Once again, we need to say that Paul's focus was much more anthropocentric. The Revised Standard Version of the Bible translates this portion of the verse as follows: '... that God may be everything to everyone'. ${ }^{19}$ In the context of the church in Corinth, where diversity was the gift and struggle of the Christian community, this focus makes perfect sense. We know that Paul proclaimed a gospel of inclusivity. ${ }^{20}$ Paul's interest was not in God

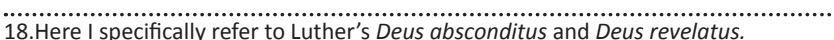
19.The Holy Bible : Revised Standard Version Containing the Old and New Testaments. (Edinburgh: Thomas Nelson and Sons, 1952).

20.See for instance Galatians 3:28. 
redeeming the whole of creation, but the lives of diverse people. The Incarnation was, in Paul's view, for human benefit, as the world and all that is in it (and of it) is confined to the neo-Platonic category of substance which, with time, will face a certain demise. The salvation of humanity is finally proclaimed with the resurrection of Christ. Christ, the first to be raised from the dead, announces the beginning of the end, leading all who responded to God's gift of grace in faith to a redeemed life.

Paul's pneumatology comes into play at this point. Romans 8:11 establishes the Holy Spirit as the vital force which transforms the human spirit into a spirit reconciled with God. For a last time, to mention that this explanation of God's redeeming work is congruent with Paul's three-tier worldview.

Deep Incarnation agrees; the resurrection is pivotal for the realisation of a reconciled state. Moritz writes: 'Deep incarnation entails deep resurrection' (Moritz 2013:441-442). The difference is only that Deep Incarnation extends the work of reconciliation to all of creation and not only to humanity. If reconciliation is only meant for humanity, then the Incarnation would ignore the relational, if not symbiotic relationship between human beings and our world. We are part of the world in which we live and the world is part of who we are (Schaab 2013:634). As stated in the previous point (the distinction between the First and Second Persons), the Word becoming flesh entails that the Incarnation absorbs the whole of humanity, the material and all its processes. This means that as '... the death of Christ becomes an icon of God's redemptive co-suffering with all of salient life as well as with the victims of social competition' (Gregersen 2001:205), so is the resurrection the universal proclamation of God's interest and participative journey with creation towards wholeness.

From the perspective of emergence and complexity theory, the Incarnation is not only for human benefit, but is in God's interest as well. Although traditional Christian theology paints the picture of salvation as, for lack of a better description, God's act of philanthropy, complexity theory suggests something more. For God to remedy brokenness at a lower level, God also contributes towards God's own wholeness at God's level of complexity. This sounds a bit hedonistic. Let us put it in a different way. By God remedying the schism at the level of creation, God is true to Godself by putting into action the twofold law of love, but 'from above'. God redeems and so doing, manifests love (for God). Secondly, God manifests the 'love for others as God loves Godself' by facilitating a state of true reconciliation with creation. In more orthodox terms, Moltmann (1996:321-340) describes this eschatological soteriology as 'Divine eschatology'.

This does not mean that the cosmos, and the Earth in particular will exist ad infinitum. No, science tells us that the Earth is certain to meet its end in the future. The human species will most probably not succeed in maintaining its own place in the cosmos, and even if we manage to travel to a habitable planet, it is only a matter of time before $H$. s. sapiens will grow into a species which has adapted to its new environment. The point is that we are once again trying to understand history, Incarnation, soteriology and even eschatology within the framework of human perceptual dimensions. Deep Incarnation includes all these processes, the manifestations of life before and life after, levels of complexity below and above to the point where from our level of complexity, we can say with confidence that the Incarnation facilitated and continuously facilitates the reconciliation of God and creation so that 'God may be all in all'.

\section{Conclusion}

This article started off by posing a few hypothetical questions. What is our place as humans in creation? Was Jesus meant only for $H$. s. sapiens? How far does Incarnation go? Can science and religion find commonplace in addressing these questions?

It is quite evident that if we were to apply a strictly Pauline theological response, we would conclude that humanity is central to God's interaction with creation. Furthermore, that sin and the remedy for sin are located in the realm of creation, specifically humankind. In order for restoration to take place, God became Incarnate from heaven 'above' to earth 'below' in the form of human flesh. In the Incarnation, life, death and resurrection of Christ, God accomplishes the mode by which humanity is restored to God, empowering new life through the power of the Spirit. Although this approach makes religious sense, it needs to be noted that it is based on Paul's cosmological understanding and may prove troublesome for those in modern times who do not adhere to Paul's worldview of a three-tier universe.

Our knowledge of complexity theory, in conjunction with Deep Incarnation, suggests that there is another way to interpret the Incarnation and salvific work of Christ which neither contradicts Christian orthodoxy nor ignores recently acquired scientific knowledge. Working from the same threepoint formulation of 1 Corinthians 15:28, it suggests that God is not only distinct from creation, but is also distinctly integrated with creation. Taking cognisance that the cosmos as we know it, and life as experience on earth forms part of cyclical development, including evolutionary processes, the Incarnation becomes the meeting point between God and the material in all its totality. Through the Incarnation, God affirms creation's part in the fullness of God's being and hence redeems not only humankind, but all flesh and its accompanying processes. In short, it means that Jesus became Incarnate for $H$. naledi too, as well as the hominids which will hopefully succeed us (if we manage not to make ourselves extinct). Perhaps the extensive impact of Deep Incarnation can be summed up in Gregersen's words: 'Deep incarnation thus suggests that God not only tolerates material existence, but also accepts it and incorporates it in a divine embrace' (Gregersen 2013a:375). 


\section{Acknowledgements Competing interests}

The author declares that he has no financial or personal relationships which may have inappropriately influenced him in writing this article.

\section{References}

Bauckham, R., 1999, God will be all in all: The Eschatology of Jürgen Moltmann, T. \& T. Clark Publishers, London.

Chown, M., 2014, Quantum theory cannot hurt you: Understanding the mind-blowing building blocks of the universe, Faber \& Faber, Washington, DC.

Dawkins, R., 2006, The God Delusion, Bantam Press, London.

Edwards, D., 2015, 'Incarnation and the natural world: Explorations in the tradition of Athanasius', in N.H. Gregersen (ed.), Incarnation: On the scope and depth of Christology, pp. 157-176, Fortress Press, Minneapolis, MN.

Engberg-Pedersen, T., 2009, 'The material spirit: Cosmology and ethics in Paul', New Testament Studies 55(2), 179-197. http://dx.doi.org/10.1017/S0028688509000125

Giberson, K.W., 2015, Saving the original sinner: How Christians have used the Bible's first man to oppress, inspire, and make sense of the world, Beacon Press, Boston, MA.

Gould, S.J., 2002, Rocks of ages: Science and religion in the fullness of life, Kindle edition, Ballantine Books.

Gregersen, N.H., 2001, 'The Cross of Christ in an evolutionary world', Dialog 40(3), 192-207. http://dx.doi.org/10.1111/0012-2033.00075

Gregersen, N.H., 2010, 'Deep Incarnation: Why evolutionary continuity matters in Christology', Toronto Journal of Theology 26(2), 173-187. http://dx.doi.org/ 10.3138/tjt.26.2.173

Gregersen, N.H., 2013a, 'Cur Deus Caro: Jesus and the cosmos story', Theology and Science 11(4), 370-393. http://dx.doi.org/10.1080/14746700.2013.836891
Gregersen, N.H., 2013b, 'Deep Incarnation and Kenosis', in with, under, and as: A response to Ted Peters', Dialog 52(3), 251-262. http://dx.doi.org/10.1111/dial. 12050

Gregersen, N.H., 2013c, 'God, information and complexity: From descriptive to explorative metaphysics', Theology and Science 11(4), 394-423.

Harari, Y.N., 2015, Sapiens: A brief history of humankind, Harper, New York, NY.

Karo, R. \& Friedenthal, M., 2008, 'Kenōsis, Anamnēsis, and our place in history: A neurophenomenological account', Zygon 43(4), 823-836. http://dx.doi.org/ 10.1111/j.1467-9744.2008.00962.x

Kauffman, S.A., 2015, 'Natural Incarnation: From the possible to the actual', in N.H. Gregersen (ed.), Incarnation: On the scope and depth of Christology, pp. 289-308, Fortress Press, Minneapolis, MN.

Lamoureux, D.O., 2011, 'Was Adam a real person?', Christian Higher Education 10(2) 79-96. http://dx.doi.org/10.1080/15363759.2010.544612

Meddings, J., 2013, 'Nonoverlapping Magisteria: Why Gould got it wrong', The Australian Rationalist 90, 19-20.

Moltmann, J., 1990, The way of Jesus Christ: Christology in Messianic Dimensions, SCM Press, London.

Moltmann, J., 1996, The coming of God: Christian Eschatology, SCM Press, London.

Moltmann, J., 2015, 'Is God Incarnate in All That Is?', in N.H. Gregersen (ed.) Incarnation: On the scope and depth of Christology, pp. 119-132, Fortress Press, Minneapolis, MN.

Moritz, J.M., 2013, 'Deep Incarnation and the Imago Dei: The Cosmic Scope of the Incarnation in Light of the Messiah as the Renewed Adam', Theology and Science 11(4), 436-443. http://dx.doi.org/10.1080/14746700.2013.836893

Peterson, D.J., 2014, 'Beyond Deep Incarnation: Rethinking Christology in Radica Lutheran Terms', Dialog 53(3), 240-249. http://dx.doi.org/10.1111/dial.12121

Rolston, H., 2015, 'Divine presence - Causal, cybernetic, caring cruciform: From information to incarnation', in N.H. Gregersen (ed.), Incarnation: On the scope and depth of Christology, pp. 255-88, Fortress Press, Minneapolis, MN.

Schaab, G., 2013, 'Incarnation as emergence: A transformative vision of God and the cosmos', The Heythrop Journal 54, 631-644. http://dx.doi.org/10.1111/heyj. 12016

Walker, W.A., 2015, The Incarnation and Kenosis, Booktango. 